\title{
Microanalysis Society
}

Established 1966

doi:10.1017/S1431927614013178

Officers 2014

Executive Council

President Kristin L. Bunker

President Elect Thomas F. Kelly

Past President John F. Mansfield

Secretary Heather A. Lowers

Treasurer Daniel T. Kremser

Directors Patrick P. Camus

Elaine F. Schumacher

Jeffrey M. Davis

Brian P. Gorman

Keana Scott

Brendan Foran

\section{Committee Chairs}

\section{MAS Past Presidents}

$$
\begin{aligned}
\text { Archivist } & \text { John H. Fournelle } \\
\text { Affiliated Regional Societies and } & \\
\text { Tour Speaker } & \text { Valerie Woodward } \\
\text { Awards Committee Chair } & \text { Paul G. Kotula } \\
\text { Computer Activities Chair } & \text { Nicholas W.M. Ritc } \\
\text { Corporate Liaison } & \text { Vernon E. Robertso } \\
\text { Education Committee Chair } & \text { Inga Holl Musselman } \\
\text { Finance Committee Chair } & \text { Joseph R. Michael } \\
\text { International Liaison } & \text { Edward P. Vicenzi } \\
\text { Membership Services } & \text { Karen Wright } \\
\text { Microscopy and Microanalysis Ed Board } & \text { Masashi Watanabe } \\
\text { MicroNews Editor } & \text { Heather A. Lowers } \\
\text { Strategic Planning Chair } & \text { Ian M. Anderson } \\
\text { Sustaining Members Chair } & \text { Lucille A. Giannuzzi } \\
\text { Topical Conferences Chair } & \text { Paul K. Carpenter }
\end{aligned}
$$

1968 L.S. Birks

1969 K.F.J. Heinrich

1970 R.E. Ogilvie

1971 A.A. Chodos

1972 K. Keil

1973 D.R. Beaman

1974 P. Lublin

1975 J.E. Colby

1976 E. Lifshin

1977 J.I. Goldstein

1978 J.D. Brown

1979 D.F. Kyser

\author{
1980 O.C. Wells \\ 1981 J.R. Coleman \\ 1982 R.L. Myklebust \\ 1983 R. Bolon \\ 1984 D.C. Joy \\ 1985 D.E. Newbury \\ 1986 C.G. Cleaver \\ 1987 C.E. Fiori \\ 1988 W.F. Chambers \\ 1989 D.B. Wittry \\ 1990 A.D. Romig, Jr
}

1991 J.T. Armsrong

1992 D.B. Williams

1993 T.G. Huber

1994 J.A. Small

1995 J.J. McCarthy

1996 D.E. Johnson

1997 J.R. Michael

1998 R.B. Marinenko

1999 J.J. Friel

2000 C.E. Lyman

2001 R.W. Linton
2002 G.P. Meeker
2003 E.S. Etz
2004 P.K. Carpenter
2005 I.H. Musselman
2006 R. Gauvin
2007 P.G. Kotula
2008 I.M. Anderson
2009 C. Johnson
2010 E.P. Vicenzi
2011 J.H.J. Scott
2012 J.F. Mansfield
2013 Kristin Bunker

\section{MAS Sustaining Members}

Advanced MicroBeam, Inc.

Bruker Nano

CAMECA Instruments, Inc.

Carl Zeiss Microscopy, LLC

EDAX, Inc.

Electron Microscopy Sciences

FEI Company

Gatan, Inc.

Geller MicroÅnalytical Laboratory

Hitachi High Technologies America, Inc.
Hysitron, Inc.

IBSS Group

IXRF Systems, Inc.

JEOL USA, Inc.

L.A. Giannuzzi \& Associates, LLC

Lehigh University

Leica Microsystems, Inc.

Materials Analytical Services, LLC

Micron, Inc.

Oxford Instruments, Inc.
Probe Software, Inc.

PulseTor, LLC

SEMTEC Laboratories, Inc.

SEMTech Solutions, Inc

South Bay Technologies, Inc.

SPI Supplies/Structure Probe, Inc.

Ted Pella, Inc.

Thermo Fisher Scientific, Inc. 


\section{MAS Awards}

All MAS Awards are recommended by the Awards Committee for approval by either the President or Council.

Peter Duncumb Award for Excellence in Microanalysis Sponsored by Bruker Nano. The Duncumb Award recognizes outstanding achievement over a sustained period of time in the field of microanalysis through technical accomplishment, leadership, and educational and pro-fessional activities. The award winner is chosen through nomi-nation by the MAS membership and selection by vote of MAS Council.

\section{Presidential Service Award}

This award honors a member of MAS for outstanding volunteer service to the society over a sustained period of time. The award winner is chosen annually by the MAS President.

\section{Presidential Science Award}

This award honors a senior scientist for outstanding technical contributions to the field of microanalysis over a sustained period of time. The award winner is chosen annually by the MAS President.

\section{K. F. J. Heinrich Award}

This award honors a scientist under the age of forty for distin-guished technical contributions to the field of microanalysis. The award winner is chosen annually by the MAS President.

\section{M\&M Student Awards}

These awards are presented annually to students presenting high quality technical papers with significant microanalysis content at the annual meeting. The award is comprised of complimentary registration and significant funds to defray travel expenses to attend the meeting. Application is accomplished by requesting consideration for a student award during the paper submission process. Qualified applicants must be fulltime students at an accredited educational institution, must be first author of the paper submitted for consideration, and must present the paper in person at the meeting. MAS Distinguished Scholars receive invitations to attend MAS-sponsored functions throughout the week of the annual meeting, including the Presidents' Reception and the MAS Social. The award winners are chosen annually by the MAS Presidentt.

\section{MAS Outstanding Paper Awards}

These awards are presented annually to the authors of outstanding papers from the previous annual meeting in each of four catego-ries. The four awards are as follows:

- Birks Award, for best contributed paper Sponsored by JEOL USA. Inc.

- Macres Award, for best instrumentation or software paper - Sponsored by Oxford Instruments, Inc.

- Cosslett Award, for best invited paper Sponsored by MAS

- Castaing Award, for best student paper. Sponsored by CAMECA Instruments, Inc.

Candidates for the MAS Outstanding Paper Awards are nominated, through consultation with symposium organizers and the MAS membership, by the MAS Directors in their final year of service at the time of the meeting, then approved by vote of MAS Council. 


\section{MAS Awards}

\section{Previous Award Winners}

Presidential Science

1977 R. Castaing
1978 K.F. Heinrich
1979 P. Duncumb
1980 D.B. Wittry
1981 S.J. Reed
1982 R. Shimizu
1983 J. Philibert
1984 L.S. Birks
1985 E. Lifshin
1986 R. Myklebust
1987 O.C. Wells
1988 J.D. Brown
1989 J. Hillier
1990 T.E. Everhart
1991 J.I. Goldstein
1992 G. Lorimer \& G. Cliff
1993 D.E. Newbury
1994 D.C. Joy
1995 G. Bastin
1996 A.V. Somlyo \& A.P. Somlyo
1997 D.B. Williams
1998 F.H. Schamber
1999 R.A. Sareen
2000 R.F. Egerton
2001 P.E. Batson
2002 K. Keil
2003 P.E. Russell
2004 J.T. Armstrong
2005 M. Slodzian
2006 B.J. Griffin
2007 R.D. Leapman
2008 T.F. Kelly
2009 J.R. Michael
2010 J. Donovan
2011 P. J. Statham
2012 N. Zaluzec
2013 P. Echlin

\section{Presidential Service}

1977 P. Lublin

1978 D.R. Beaman

1979 M.A. Giles

1980 A.A. Chodos

1981 R. Myklebust

1982 J. Doyle

1983 D. Newbury

1984 J.I. Goldstein

1985 M.C. Finn

1986 V. Shull

1987 D.C. Joy

1988 G. Cleaver

1989 W.F. Chambers

1990 E. Fiori

1991 T.G. Huber

1992 E.S. Etz

1993 H.A. Freeman

1994 J.L. Worrall

1995 R.W. Linton

1996 P.F. Hlava

1997 J.A. Small

1998 J.J. McCarthy

1999 T.G. Huber

2000 R.B. Marinenko

2001 C.E. Lyman

2002 J.F. Mansfield

2003 I.H. Musselman

2004 J.R. Michael

2005 G. Meeker

2006 H.A. Freeman

2007 P.K. Carpenter

2008 L.M. Ross

2009 V. Woodward

2010 S. Wight

2011 D. Kremser

2012 C. Johnson

2013 J.J. McGee

\section{K.F.J. Heinrich}

1986 P. Statham

1987 J.T. Armstrong

1988 D.B. Williams

1989 R. Leapman

1990 R.W. Linton

1991 A.D. Romig, Jr.

1992 S. Pennycook

1993 P.E. Russell

1994 J.R. Michael

1995 N. Lewis

1997 R. Gauvin

1998 V.P. Dravid

1999 J. Bruley

2000 H. Ade

2001 C. Jacobsen

2002 D. Wollman

2005 M. Watanabe

2006 M. Toth

2007 G. Kothleitner

2008 P.G. Kotula

2009 D. Drouin

2010 H. Demers

2011 L. Brewer

2012 E. Marquis

2013 J. LeBeau

Peter Duncumb Award for

Excellence in Microanalysis

2007 D.B. Williams

2008 J.I. Goldstein

2009 D.E. Newbury

2010 D. Joy

2011 J. Michael

2012 J. Bentley

2013 E. Lifshin 


\section{MAS 2014 Awards}

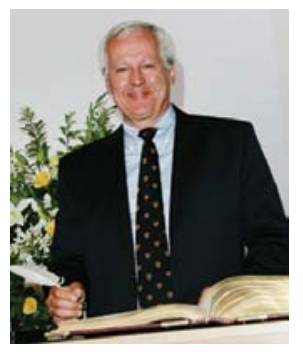

\section{Duncumb Award for} Excellence in Microanalysis Ondrej Krivanek

Ondrej Krivanek graduated with a B.Sc. in Physics from Leeds University and a Ph.D. from Cambridge University, both in the UK. He was a postdoctoral fellow at Kyoto University, Bell Laboratories and the University of California at Berkeley, assistant professor of Physics at Arizona State University, director of research at Gatan, visiting professor at Tokyo Institute of Technology, CNRS Orsay and Cambridge University, and research professor at University of Washington. In 1997, he co-founded Nion Company near Seattle in Washington State. He has since been Nion's president and more recently also adjunct professor of physics at Arizona State University.

During his post-doc at Berkeley, Ondrej found that he liked thinking up, designing, making and then using pioneering new instruments more than working with existing ones, and later on that instrument development can often be done more effectively in a small company setting than in academia. Instruments whose design he originated, such as Gatan's electron energy loss spectrometers and imaing fiters, CCD cameras and DigitalMicrograph sofware, and more recently electron-optical aberration correctors and Nion's whole electron microscopes and monochromators, can be found in many laboratories around the world, and they have helped to produce many scientific advances. The Nion microscopes in particular have been able to explore matter in unprecedented detail, including, very recently, performing phonon spectroscopy and spectrum-imaging in an electron microscope.

Ondrej has published over 240 papers and book chapters, with over 6000 citations. His work has been honored by an R\&D 100 award, the Seto Prize of the Japanese Microscopy Society, the Duddell Prize of the Institute of Physics, the Distinguished Scientist Award of the Microscopy Society of America, an Honorary Fellowship in the Royal Microscopical Society, and an election to the British Royal Society.

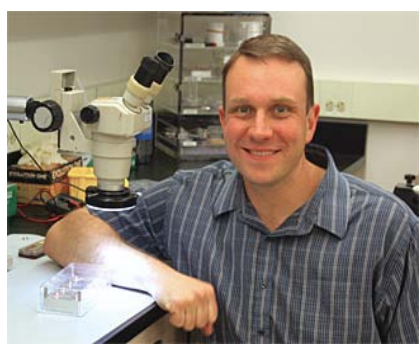

\section{K.F.J. Heinrich Award} Brian Gorman

Brian Gorman is currently an Associate Professor of Materials Science at the Colorado School of Mines. Brian earned his B.S., M. S., and Ph.D. in Ceramic Engineering at the University of Missouri - Rolla (now Missouri S\&T) under the direction of Harlan Anderson. After his graduate work, he joined the Department of Materials Science and Engineering at the University of North Texas as a postdoctoral researcher in close collaboration with Texas Instruments. Brian went on to teach at UNT for 5 years while working on summer sabbatical at the National Renewable Energy Laboratory in Golden, CO. He joined the faculty at the Colorado School of Mines in 2009, again working closely with NREL and NIST-Boulder.

Brian's research group focuses on developing and applying correlative atom probe tomography and transmission electron microscopy techniques to determine the atomic scale structure and chemistry of ceramics and semiconductors. Recently, his group has been focusing on ferroelectric and dielectric oxide ceramics, CdTe and CIGS photovoltaics, GaN nanostructures, transparent conducting oxides, and ion conducting oxides. Brian's goal with APT is to directly determine the electrical, optical, and mechanical properties of these materials from the 3-D atomic scale chemistry. His group is also developing in-situ annealing techniques for atomic scale diffusion measurements using laser pulsed APT.

Brian has been an active contributor to the M\&M annual meeting by chairing many technical sessions on FIB and APT. Currently, Brian serves as a Director of MAS. He has co-authored over 60 journal publications and has given over 70 invited presentations at national and international conferences. 


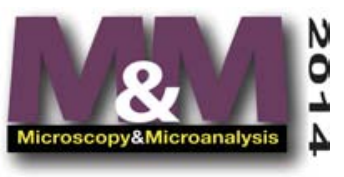

\section{MAS 2014 Awards}

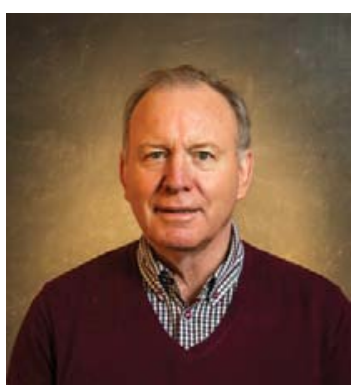

Presidential Science

Award

Hamish L. Fraser

Hamish L. Fraser graduated from the University of Birmingham (UK) with the degrees of B.Sc. (1970) and Ph.D. (1972). He was appointed to the faculty of the University of Illinois in 1973 (Assistant, Associate and Full Professor), before moving in 1989 to the Ohio State University (OSU) as Ohio Regents Eminent Scholar and Professor. He was appointed as a Senior Research Scientist at the United Technologies Research Center from 1979-1980. He has also been a Senior von Humboldt Researcher at the University of Göttingen, a Senior Visitor at the University of Cambridge, a visiting professor at the University of Liverpool, and spent a sabbatical leave at the Max-Planck Institut für Werkstoffwissenscahften in Stuttgart. He has been an Honorary Professor of Materials and Technology at the University of Birmingham since 1988. In 2014, he was recognized as an Honorary Professor at the Nelson Mandela Metropolitan University in Port Elizabeth, South Africa.

At present, he serves as Director of the Center for the Accelerated Maturation of Materials (CAMM) at OSU. He has been a member of the National Materials Advisory Board and the US Air Force Scientific Advisory Board. He has consulted for a number of national laboratories and several industrial companies. He is a Fellow of TMS, ASM, IOM3 (UK), and MSA. He has published over 380 papers in scholarly journals, and given over 280 invited presentations. He has grauated 48 doctoral students and 36 students graduating with the degree of M.S.

His work is based on research involving the development of advanced methods of materials characterization (involving high resolution and analytical electron microscopy), materials processing, and microstructure/property relationships. Dr. Fraser has an active research program in the development of new and improved materials, including: advanced materials characterization, direct 3-D microstructural representation, modeling microstructure/properties in light alloys, with an emphasis at present on $\mathrm{Ti}$ alloys, development of creep resistant beta-Ti alloys, development of low modulus beta$\mathrm{Ti}$ alloys for orthopedic implants, and powder metallurgy, including additive manufacturing (LENS ${ }^{\mathrm{TM}}$, hot isostatic pressing (HIP), and Kinetic Metallization). More recently, he has concentrated effort on establishing and developing the CAMM.

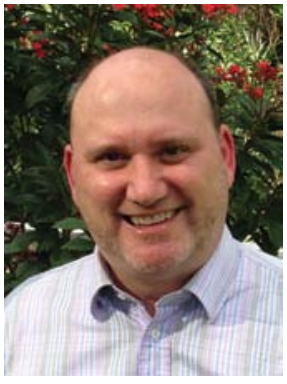

\section{Presidential \\ Service Award}

Ian M. Anderson

Ian M. Anderson has been a member of the Microanalysis Society since 1991. He became involved in MAS through the Society's technical programming, having organized numerous symposia beginning in 1996, the first Microscopy \& Microanalysis (M\&M) meeting. He served as Program Chair for M\&M 2004. Ian has also been strongly involved in the Society's governance. He has served as Director (1999-2001) and President (2007-2008) of the Society. More recently he has served as Chair of the Strategic Planning Committee (2010-2014).

Ian's activities in MAS have focused on shoring up the foundations of the Society and in the involvement of a larger cross-section of the Society's membership in its activities. He oversaw the transition to standing comittees of roles that had been filled for many years by dedicated individuals, in particular the establishment of Finance and Awards Committees. Ian is honored to receive the Society's Presidential Service Award. 